\title{
Na-Alginate Utilization of Brown Algae (Sargassum sp.) as A Halal Edible Film Basic Materials
}

\author{
Nisa Nur Khasanah", Vina Amalia ${ }^{1}$, Baiq Vera El Vierai ${ }^{1}$, Asti Sawitri ${ }^{2}$ \\ ${ }^{1}$ Department of Chemistry, Faculty of Science and Technology UIN Sunan Gunung Jati Bandung \\ Jl. A.H. Nasution No. 105 Cipadung, Bandung 40614 \\ ${ }^{2}$ Department of Physics, Faculty of Science and Technology UIN Sunan Gunung Jati Bandung \\ Jl. A.H. Nasution No. 105 Cipadung, Bandung 40614 \\ Correspondent email: vinaamalia@uinsgd.ac.id
}

\begin{abstract}
Edible films made of Na-alginate from brown algae have great potential to be developed as brown algae have a fairly high abundance in Indonesia but have not been widely used. Therefore, this study is conducted by making edible films made from Na-alginate modified by the addition of hydrocolloids carrageenan and glycerol plasticizier. The addition of carrageenan biopolymers is the property of the produced Edible film. The use of glycerol as a plasticizer aims to improve the properties of elasticity of Edible films. This research method consists of two stages. First stage is the isolation and characterization of Na-alginate, and second is the preparation and characterization of making edible films. Na-alginate characterization results in yield of 25.68\%, 10.84\% moisture content, and $23.79 \%$ ash content. The carrageenan on the Edible film formula affects the characterization of the resulting films. The value of water absorption from $333.13 \%$ to $335.45 \%$ and the elongation of $26.26 \%$ to $33.34 \%$, and the declining value of tensile strength of $8.93 \mathrm{MPa}$ to $4.17 \mathrm{MPa}$ and young's modulus values of $0.34 \mathrm{MPa}$ to $0.22 \mathrm{MPa}$ with the addition of carrageenan on an Edible film formula.
\end{abstract}

Keywords : Brown algae, Edible films, Glycerol, Carrageenan, Na alginate.

\section{Introduction}

Product packaging based on the development of organic or biodegradable plastic materials today was developed. One form of developing biodegradable plastic is edible film. The development of environmentally friendly edible film can be applied to food packaging that can provide better product quality, can extend the durability of food products, and can be eaten directly, so that this packaging does not cause pollution to the environment.

On the other hand, the manufacture of biodegradable plastics often uses basic ingredients derived from animal fat. Animal fats are often used mainly from domestic animals such as cattle, goats and pigs. Collagen originating from cows and goats has a high selling price, in contrast to collagen derived from pork which is cheaper and easier to find. This has caused many producers of biodegradable plastic packaging products to use collagen derived from pigs. This becomes a problem for Muslims who consume these products. The problems that arise, namely in terms of halal. Therefore, start developing a type of packaging that is derived from natural materials that fit into the category of halal food. One of the natural materials that can be used as a basis for making edible film is brown algae.

Brown algae is one of the abundant natural resources in Indonesia. This abundance of resources can support economic growth and increase potential in the field of research. One type of brown algae that can be used is Sargassum sp. The growth of Sargassum $\mathrm{sp}$ in Indonesia is spread in several waters such as Sumatra, Java, Bali and Kalimantan.

The population of Sargassum sp, a species of alginateproducing brown algae, is quite a lot. The alginate content in Sargassum sp brown algae ranges from 8$23 \%$ depending on the conditions of regrowth (Anggadiredja, Zantika, H, \& S, 2006). The use of alginates in Indonesia is quite wide, including in the fields of industry, pharmacy and food. With insulation and modification, alginate can be used as a thin film used as a membrane wrapper or packaging material for food products.

Edible film alginate is formed by evaporation of alginate solutions followed by binding of calcium salts (Fehragucci, 2012). The alginate film produced will have good barrier properties against $\mathrm{O}_{2}$ at low temperatures, can inhibit lipid oxidation in packaged products, and can improve the taste and texture of the product. In addition to these properties, edible films have the disadvantage that alginates can be easily damaged when drying, but can be anticipated by adding plasticizers and other biopolymers that can cover the lack of edible film alginates.

Plasticizier is a low molecular weight material added in a compound with the aim of increasing elasticity, 
namely by changing the physical and mechanical properties of this compound. Plasticizier commonly used in making edible films is glycerol as hydrophilic and low molecular weight.

Carrageenan is a polysaccharide compound and also a hydrocolloid compound consisting of potassium, sodium, magnesium, and potassium sulfate esters with 3.6 galactose anhydridogalactose copolymers (Winarno, 1996). Carrageenan has hydrophilic properties, namely the basic ingredients of edible film as a good barrier to oxygen, carbon dioxide and lipids. Besides, carrageenan has also been widely used in the food sector for food packaging, cleaning products, fatty foods, and drug capsules.

Based on the above, a study was conducted to determine the characteristics of alginate edible film with glycerol and the addition of carrageenan biopolymers. The use of alginate as a raw material for edible film because alginate has a polymeric component in the form of polysaccharides (carbohydrates) that are thermoplastic in nature, so that it has the potential to be formed or printed as edible films that fall into the halal food category. In addition, the selection of carrageenan as a hydrocolloid mixture aims to determine the effect of hydrocolloid hydrophilic addition on the edible properties of the film produced. The use of glycerol as a plasticizier and the addition of carrageenan biopolymer as a hydrocolloid mixture are expected to provide a synergistic interaction, so that the characteristics of edible films become better (Farag et al. 2015).

\section{Materials and methods}

\subsection{Materials}

The main material used in this experiment was brown algae obtained from the beach of Minajaya Sukabumi. The other material used at the experiment were $\mathrm{HCl}$ $1 \%$ and $15 \%, \mathrm{Na}_{2} \mathrm{CO}_{3} 2 \%$, aquadest, $\mathrm{NaOH} 0,5 \%$ and $10 \%, \mathrm{H}_{2} \mathrm{O}_{2} 10 \%$, Isopropyl Alcohol, $\mathrm{CaCl}_{2} \mathrm{0,2} \mathrm{M}$, glycerol plasticizier, carrageenan, and Whatmann filter paper.

\subsection{Extraction of Na-Alginate from brown-algae}

Algae are dried and soaked using $1 \% \mathrm{HCl}$ with a ratio of 1:30 w/v (algae: $\mathrm{HCl}$ ) until 1 hour, and then washed using aquadest to neutral $\mathrm{pH}$. The preparation result of algae was soaked in $0.5 \% \mathrm{NaOH}$, then extracted using $\mathrm{Na}_{2} \mathrm{CO}_{3} 2 \%$ with a ratio of $1: 30 \mathrm{w} / \mathrm{v}$ at a temperature of $60-70^{\circ} \mathrm{C}$ for 2 hours. After that, filtration is carried out to separate the residue and filtrate. Then the obtained filtrate was blanched using $10 \% \mathrm{H}_{2} \mathrm{O}_{2}$ while stirring and allowed to stand for 30 minutes. The Alginic acid is formed by adding $15 \% \mathrm{HCl}$ until $\mathrm{pH}$ of the sample to 2-3. Furthermore, the alginic acid formed is converted to Na-alginate by adding $10 \% \mathrm{NaOH}$ to neutral $\mathrm{pH}$. Then the separation is done by adding 1:2 v/v isopropyl alcohol. After that, filtering sample and drying used the oven for about 24 hours until the moisture content was $12 \%$. The next process was grinding using a grinder to obtained Na-alginate powder and then analyzed the physical and chemical properties. The characterization of the chemical structure of Na- Alginate used Fourier transform infrared (FTIR) technique.

\subsection{Fabrication of Edible Film}

A $5 \mathrm{~g}$ of Na-alginate and $100 \mathrm{ml}$ of aquadest were stirred slowly until a homogeneous solution was formed. After that, an $0.5 \mathrm{M} \mathrm{CaCl} 2$ was added with a ratio of $1: 10 \mathrm{v} / \mathrm{v}$ and then mixed until homogeneous. The ca-alginate solution is divided into 2 variations, namely solution without addition carrageenan and solution with the addition carrageenan and mixed until homogeneous. After that, added $10 \%$ glycerol until an edible film solution formed. The characterization of the chemical structure of the edible film used Fourier transform infrared (FTIR) technique.

\subsection{The Mechanical characterization}

The film thickness was measured using a screw micrometer. The average thickness was determined by measuring thickness at 5 different points at the film. The tensile strength was measured the Testometric Tensile (M350-10AT) at Balai Besar Tekstil. The sample clamped with a tensile testing machine. Next, record the thickness and initial of the sample length. Samples are pulled at a speed of $100 \mathrm{~mm} / \mathrm{minute}$ until break. This tensile strength test was carried out on three samples of the edible film which were then averaged. The tensile strength of the edible film can be calculated using Eq. (1)

$$
\tau=\frac{F \max }{A}
$$

where $\tau$ is tensile strength (MPa), $\mathrm{F}_{\max }$ is maximum stress $(\mathrm{N})$, and $\mathrm{A}$ is cross-section area $\left(\mathrm{mm}^{2}\right)$.

The elongation measurement method was the same as tensile strength testing. The elongation was expressed as a percentage and can be calculated using Eq. (2)

$$
\begin{gathered}
\text { The elongation }(\%)= \\
\frac{\text { the strain when break }(\mathrm{mm})}{\text { the initial length }(\mathrm{mm})} \times 100 \%
\end{gathered}
$$

The elasticity (modulus young) is obtained from the divide between tensile strength and elongation.

\subsection{Water Resistance characterization}

The first step of water resistance characterization was weighing the initial mass of the edible film (Wo). Furthermore, the edible film soaked in aquadest for 10 seconds. Then the sample is removed from aquadest and the water on surface of the film is removed with a paper tissue. The water resistance by the sample was calculated by the Eq (3).

$$
\text { Water }(\%)=\frac{W-W o}{W o} \times 100 \%
$$


where $\mathrm{W}$ is the weight of wet edible film and $\mathrm{W}_{\mathrm{o}}$ is the weight of dry edible film.

\section{Result and discussion}

\subsection{Characterization of Na-alginate that resulting from extraction}

Na-alginate-making process is done by extracting dried brown algae that has been sorted. the extraction aims to release alginate from cellulose and separating it from other components in order to obtain pure Naalginate. Na-alginate obtained will be used in the next stage as a raw material edible film.

\section{a. The yield value of $\mathrm{Na}$-alginate}

The yield of Na-alginate showed the percentage of alginate extracted from brown algae which binds to sodium ions. The percent yield of Na-alginate in this study produced a value of $25.69 \%$. This yield value is smaller than the research carried out by Wahyu Musholaeni (Wahyu Mushollaeni, 2011) with a percent yield of $30.5 \%$.

The difference in percent yield can be caused by the viscosity of the filtrate produced after a different extraction process. This is because the imperfect filtering process causes the alginate extract to remain in the residue. In addition, the stirring technique is less than perfect during the refining process so that Isopropanol cannot attract alginate properly and the resulting percent yield is lower.

\section{b. Water content of Na-alginate}

The results of the analysis of water content in $\mathrm{Na}$ alginate produced in this research that is equal to $10.84 \%(w / w)$. When compared with Na-alginate produced by Haerunnisa that is equal to $12: 45 \%$, the water content of Na-alginate generated in this study are smaller (Haerunnisa, 2008). However, the value of the water content of the research has been qualified set by the FCC (1993) that is less than $15 \%$. Types of algae used and native habitat of the algae can cause the value of the water content of each of the different algae.

Water content in Na-alginate can also be influenced by the addition of isopropyl alcohol compound as a purifying agent in the process of extraction, drying and storage of Na-alginate powder. Isopopil has the ability to bind water in the alginate solution so that the alginate can settle, but in the process can allow the water that is still bound to the sediment that may affect the value of the water content.

\section{c. Ash content of Na-alginate}

The ash content is a representation of the various components of the inorganic or mineral contained in a food. In Table 1. The ash content contained in the Naalginate extraction results, showed the presence of mineral salts or anorganic compounds with $22.06 \%$ value. The ash content values was close to the ash content value that has been determined by Haerunnisa (2008) that is $23.27 \%$. This value also meets FCC standards that can be seen in Table 1. Similarly with the water content, ash content is very important to determine the degree of purity of the product.

The composition of brown algae minerals depends on the presence of seawater mineral salts. In general, the most composition of the mineral salts are halogen compounds ( $\mathrm{Br}$ and I), as well as sodium and chlorine compounds in the relatively low number. The ash content can also be affected by the immersion process using $\mathrm{HCl}$ which is less than optimal. This soaking process aims to eliminate the salts or other impurities contained in the sample to be processed.

\section{d. Viscosity}

The viscosity of Na-alginate will describe the quality of Na-alginate itself because generally in the alginate industry it is used as a thickener and emulsifier. In this study, the extracted viscosity of alginate was $36 \mathrm{cPs}$. The standard viscosity of alginate in $1 \%$ alginate solution at $25^{\circ} \mathrm{C}$ is $10-1000 \mathrm{cPs}$, so the viscosity value obtained in this study is still in the standard viscosity for $\mathrm{Na}$-alginate. The viscosity of $\mathrm{Na}$-alginate is influenced by the $\mathrm{pH}$ of $\mathrm{Na}$-alginate. The viscosity of $\mathrm{Na}$-alginate will increase at $\mathrm{pH}>6$ and not stable at $\mathrm{pH}$ 10 . The $\mathrm{pH}$ value of the extraction of alginate is equal to 8.2 so the value of the viscosity obtained is not too high.

Table 1. Physical Properties of Na-alginate from

Extraction

\begin{tabular}{lcc}
\hline Parameter & $\begin{array}{c}\text { Na-alginate } \\
\text { trial }\end{array}$ & $\begin{array}{c}\text { Food Chemical } \\
\text { Codex (FCC) in } \\
\mathbf{1 9 9 5}\end{array}$ \\
\hline \% yield & $25.68 \%$ & \\
Water content & $10.84 \%$ & $>15$ \\
Ash content & $23.79 \%$ & $18-27$ \\
viscosity & $36 \mathrm{cPs}$ & \\
$\mathrm{pH}$ & 8.2 & \\
\hline
\end{tabular}

\subsection{Characteristics of Edible Film}

The preparation of edible film-making is done by changing the $\mathrm{Na}$-alginate into $\mathrm{Ca}$-alginate beads with the addition of $\mathrm{CaCl} 2$. Edible films produced in this study are transparent brown as shown in Figure 1. This is caused by brown alginate powder. Each edible film produced has a different thickness. edible film $\mathrm{Ca}$ alginate + Carrageenan has a higher thickness compared to edible film Ca-alginate, with an average thickness of 0.058 and $0.044 \mathrm{~mm}$, respectively. Edible film Ca-alginate + carrageenan has a more flexible nature than edible film $\mathrm{Ca}$-alginate. This can be caused by the addition of carrageenan so that it will affect the physical and mechanical properties of edible film. 


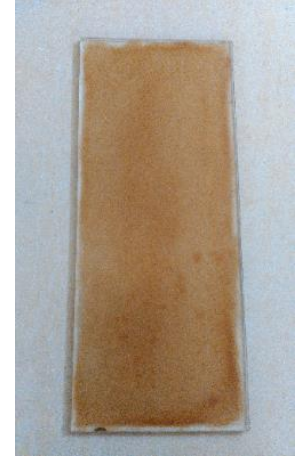

A

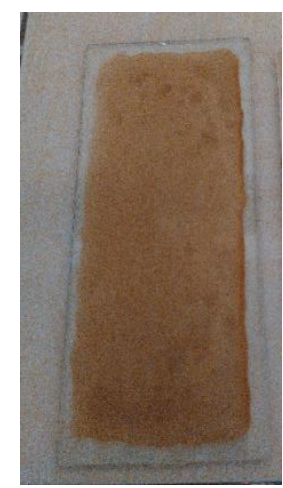

$\mathrm{B}$
Picture 1. a) Edible films Ca-alginate + Carrageenan b) Edible films $\mathrm{Ca}$-alginate

\section{a. Water resistance}

The results of the analysis of the water resistance of edible Ca-alginate films showed that carrageenan affects the water resistance of edible films. Water absorption from the resulting film can be increased by the addition of carrageenan as a hydrocolloid mixture, its value can be seen in Table 2. Addition of carrageenan and glycerol plasticizer increases the water absorption value. This happens because carrageenan has a slightly hydrophilic nature. In addition, the addition of plasticizers can also be influential because plasticizers are hydrophilic so they can attract water molecules and form a large hydrodynamic water plasticizer. So with these results it shows that in this study, carrageenan as a hydrocolloid mixture provides poor water resistance to edible film material.

\section{b. Mechanical Properties of Edible Films}

Mechanical characteristics indicate the integration of edible film under stress conditions that occur during the formation process. Mechanical properties are influenced by the formulation of edible film that is $\mathrm{Na}-$ alginate, $\mathrm{CaCl}_{2}$, carrageenan and glycerol. Carrageenan as a biopolymer mixed into $\mathrm{Ca}$-alginate provides good mechanical properties for edible film. While the addition of glycerol as a plasticizer to the mixture can give plastic properties to the edible film material.

These three parameters were tested in this study have values greater than the previous research that has been done by Helmi Fehragucci (2012) for the Ca-alginate edible film that is the value of tensile strength 6.981 and elongation $2.03 \%$. This can be caused by different concentrations of $\mathrm{CaCl} 2$. The use of the higher concentration of $\mathrm{CaCl} 2$ will cause the gel to be more stable, so that the value of the tensile strength obtained will be even greater. The edible film produced will be more rigid, this is because $\mathrm{Ca}$-alginate forms hydrogen bonds with less water than $\mathrm{Na}$-alginate

Edible films with high tensile strength will be able to protect the products they pack well from mechanical disturbances. The results of mechanical strength analysis showed that the addition of carrageenan influenced the tensile strength of the edible film produced. The resulting tensile strength decreased with the addition of carrageenan, from $8.93 \mathrm{MPa}$ to 4.17 MPa. This can be caused by the slightly hydrophobic nature of carrageenan. In addition, the use of carrageenan concentrations used can also influence the tensile strength of edible films produced in this study. The commercial tensile strength of edible film is 15.53 $\mathrm{MPa}$. Kroctha and Johnston (1997) state that the range of tensile strength values that can be applied to standard edible films is between 10-100 Mpa (Kroctha \& Gago, 1997). Thus the value of the tensile strength of edible films produced in this study has not reached the value of standard edible film or commercial edible film values (<10MPa).

The measurement of extension is carried out together with the measurement of tensile strength. The extension test aims to determine the increase in the length of the edible film before finally breaking up. The percent value of the edible film extension in this study can be seen in Table 2. Addition of carrageenan can increase the extension value so that the film matrix becomes flexible. The values of tensile strength and extension are influenced by plasticizers. The characteristics of plasticizers will reduce the strength between molecules, thereby increasing the mobility of the biopolymer chain and increasing its mechanical properties. According to Kroctha (1997) the characteristics of standard edible films have an extension percentage of $10-50 \%$. In this study the value of the extension of each edible film is included in the standard value. But with the increasing percentage (film extension), edible films are easier to stretch and expand. This can cause the surface of the film to become thinner so that the resulting edible film is torn or damaged more easily.

Table 2. Mechanical Properties Edible films and $\mathrm{Ca}$ -

Ca-Alginate Alginate + Carrageenan

\begin{tabular}{lcccc}
\hline $\begin{array}{c}\text { Type } \\
\text { edible } \\
\text { film }\end{array}$ & $\begin{array}{c}\text { Absorp } \\
\text { tion } \\
(\%)\end{array}$ & $\begin{array}{c}\text { Tensile } \\
\text { strength } \\
\text { (MPa) }\end{array}$ & $\begin{array}{c}\text { Elongat } \\
\text { ion }(\%)\end{array}$ & $\begin{array}{c}\text { Young's } \\
\text { Modulus } \\
\text { (MPa) }\end{array}$ \\
\hline $\begin{array}{l}\text { Ca- } \\
\text { alginate } \\
\begin{array}{l}\text { Ca- } \\
\text { alginate }\end{array}\end{array}$ & 333.13 & 8.93 & 26.26 & 0.34 \\
+ & & & & \\
$\begin{array}{l}\text { Carrage } \\
\text { enan }\end{array}$ & 335.45 & 4.17 & 33,34 & 0.22 \\
$\begin{array}{l}\text { Coating } \\
\text { commer } \\
\text { cial }\end{array}$ & 75.52 & 15.53 & 19.53 & 0.79 \\
\hline
\end{tabular}

The level of rigidity of edible films can be determined by measuring modulus young on edible films. Young modulus is a measure of the stiffness of a material. Young modulus is obtained from a comparison 
between tensile strength and percent extension. From Table 2. It can be seen that the young modulus $\mathrm{Ca}$ alginate non carrageenan value is higher than $\mathrm{Ca}$ alginate with the addition of carrageenan, which are $0.34 \mathrm{MPa}$ and $0.22 \mathrm{MPa}$, respectively. While the young modulus value of commercial edible films is 0.79 MPa. Small modulus values indicate that edible films are elastic. If the young modulus decreases, the flexibility of edible films increases. So that the young modulus of Ca-alginate shows that non-carrageenan $\mathrm{Ca}$-alginate has a higher rigidity so it is not too flexible (Kramer, 2009). However, when compared with edible film Ca-alginate with edible film, commercial edible film has a higher stiffness value than the $\mathrm{Ca}$-alginate edible film in this study.

The mechanical properties of the results of previous studies with the research conducted show that in this study the value of tensile strength is low, but the extension value is higher. Comparisons are also made with commercial edible film on the market. From the comparison with commercial edible film, the mechanical value and absorption of water were obtained far enough with the results of the edible film. This shows that the edible film mechanical value produced in this study has not been able to achieve the mechanical value of commercial edible film. In addition, the addition of carrageenan into edible film formulations can affect the mechanical properties of the edible film produced.

\section{Conclusion}

From the results of this study can be concluded as follows:

1. Na-Alginate from brown algae has the potential as a raw materials in making halal edible films

2. Characterization of $\mathrm{Ca}$-alginate edible film in this study has a water absorption value of $333.13 \%$, tensile strength of $8.93 \mathrm{MPa}$, elongation of $26.26 \%$, and young modulus of $0.34 \mathrm{MPa}$.

3 . The addition of carrageenan to the edible film Caalginate affects the edible properties of the film produced. The addition of carragean causes an increase in the value of water absorption to $335.45 \%$ and the elongation value to $33.34 \%$, but the reduced tensile strength to $4.17 \mathrm{MPa}$ and the young modulus to $0.22 \mathrm{MPa}$.

\section{Acknowledgement}

Thank you to the LPPM UIN SGD Bandung, who provided research funding. Thank you to the Chemistry Laboratory of the Faculty of Science and Technology of UIN Bandung, which provided facilities during this research.

\section{References}

Anggadiredja, Zantika, J., H, P., \& S, I. (2006). Rumput Laut. Jakarta: Penebar Swadaya.

FCC. (1981). Food Chemical Codex. Washington DC: National Academy Press.

Fehragucci, H. (2012). Pengaruh Penambahan Platicizer dan Kitosan terhadap Edible Film
Ca-alginat. Skripsi, Universitas Sebelas Maret, Surakarta.

Haerunnisa. (2008). Analisa Kualitas Natrium Alginat Hasil Ekstraksi Untuk Minuman Suplemen Serat dalam bentuk Effervescent. Skripsi, UIN Syarif Hidayatullah Jakarta, Jakarta.

Kramer, M. E. (2009). Structure and Function of Starch-Based Edible Films and Coatings. In M. E. Kerry C. Huber, Edible Films and Coatings for Food Applications (pp. 113134). Springer.

Krochta, J.M., E.A., Baldwin, \& M,Q. NisperosCarriedo. (1994). Edible Coating and Film to Improve Food Quality. New York: NY: Technomic Publishing Company.

Kroctha, G. M., \& Gago, P. M. (1997). Denaturation Times an Temperatur Effect on Solubility, Tensile Properties, and OxygenPermeability of Ehey Protein Edible Film. Journal an Food Science, 51, 61-74.

Rusdiana, W. M. (n.d.).

Wahyu Mushollaeni, E. R. (2011). Karakterisasi Natrium Alginat dari Sargassum sp., Turbinaria sp. dan Padina sp. Jurnal Teknologi dan Industri Pangan, XXII(1), 2632.

Winarno, F. G. (1996). Teknologi Pengolahan Rumput Laut. Jakarta: Sinar Harapan. 